\title{
TANGgUNG GUGAT PEJABAT PEMBUAT AKTA TANAH ATAS KETERLAMBATAN PENDAFTARAN AKTA PEMBERIAN HAK TANGGUNGAN SECARA ONLINE DI KANTOR PERTANAHAN
}

\author{
Fatimah Zakiyyah \\ Universitas Narotama | Jl. Arif Rahman Hakim No.5I, Klampis Ngasem, Sukolilo, \\ Kota Surabaya \\ fettyzakiyyah@gmail.com
}

\begin{abstract}
Decision Ratio of the Supreme Court. I563K/PDT/20 I0 rejected the plaintiffs' arguments (Wati Rachmawati and Herizal Febriansyah) regarding the legal defects of APHT because the PPAT transmits APHT files more than 7 (seven) days after the file that has been signed is contrary to article 13 of UUHT. However, the Supreme Court, in its verdict, rejected the arguments of the appeal from Wati Rachmawati and Herizal Febriansyah with the consideration that the appellant of appeal can not prove his or her arguments. It means that if the appellant can prove the delay in sending the file in APHT and the lawsuit is granted because Wati Rachmawati and Herizal Febriansyah are not the parties that have to prove but PPAT which makes APHT. PPAT who is late in submitting the deed of granting mortgage rights can be said to commit an unlawful act that violates the provisions of article 62 of PP. However, if it fails to prove, the PPAT can not be held liable in the form of compensation on the basis of having committed the act unlawfully as article 1365 Civil Code, due to the element of loss and the causal relationship between the act and the resulting loss is not met. Keywords: Liability, Land Acquisition Officer, Late Registration of Deed of Grant Rights
\end{abstract}

Abstrak: Ratio decidendi putusan Mahkamah Agung Nomor 1563 K/PDT/20 I 0 yang menolak dalil-dalil penggugat (Wati Rachmawati dan Herizal Febriansyah) mengenai cacat hukum APHT karena PPAT mengirimkan berkas APHT lebih dari 7 (tujuh) hari setelah berkas ditandatangani bertentangan dengan ketentuan pasal 13 UUHT. Namun Mahkamah Agung dalam putusannya menolak dalil-dalil kasasi dari Wati Rachmawati dan Herizal Febriansyah dengan pertimbangan pemohon kasasi tidak dapat membuktikan dalil-dalilnya, yang berarti 
bahwa jika pemohon kasasi dapat membuktikan keterlambatan pengiriman berkas dalam APHT, maka gugatan dikabulkan, karena yang dibebani pembuktian bukan Wati Rachmawati dan Herizal Febriansyah, melainkan PPAT yang membuat APHT. PPAT yang terlambat mengirimkan akta pemberian hak tanggungan dapat dikatakan melakukan perbuatan melanggar hukum yakni melanggar ketentuan pasal 62 PP Nomor 37 Tahun 1998, namun terhadap keterlambatan tersebut apabila Rachmawati dapat membuktikan dirinya menderita kerugian, namun jika tidak dapat membuktikan, maka PPAT tidak dapat dimintakan pertanggungan gugat berupa ganti kerugian atas dasar telah melakukan perbuatan melawan hukum sebagaimana Pasal 1365 KUH Perdata, karena unsur adanya kerugian dan hubungan kausal antara perbuatan dengan kerugian yang timbul tidak terpenuhi

Kata Kunci: Tanggung gugat, Pejabat Pembuat Akta Tanah, Keterlambatan Pendaftaran Akta Pemberian Hak Tanggungan

\section{Pendahuluan}

Jaminan dibedakan antara jaminan umum didasarkan atas ketentuan pasal 1131 Kitab Undang-Undang Hukum Perdata (selanjutnya disingkat KUH Perdata) dan jaminan khusus didasarkan atas perjanjian yang dibuat antara kreditur dengan debitur, di antaranya sebagaimana tercantum dalam pasal 1133 KUH Perdata. Khusus jaminan barang tidak bergerak berupa hak atas tanah pembebanannya dengan hak tanggungan sebagaimana diatur dalam Undang-Undang Republik Indonesia Nomor 4 Tahun 1996 Tentang Hak Tanggungan Atas Tanah Beserta Benda-Benda yang Berkaitan Dengan Tanah (selanjutnya disingkat UUHT).

Menurut pasal 1 angka 1 UUHT, mendefinisikan hak tanggungan adalah hak tanggungan atas tanah beserta bendabenda yang berkaitan dengan tanah, yang selanjutnya disebut Hak tanggungan, adalah hak jaminan yang dibebankan pada hak atas tanah sebagaimana dimaksud dalam Undang-Undang Nomor 5 Tahun 1960 tentang Peraturan Dasar Pokok-Pokok Agraria, berikut atau tidak berikut benda-benda lain yang merupakan satu kesatuan dengan tanah itu, untuk pelunasan utang tertentu, yang 
memberikan kedudukan yang diutamakan kepada kreditor tertentu terhadap kreditor-kreditor lain.

Hak atas tanah yang dibebani dengan hak tanggungan, harus dilakukan sesuai dengan prosedur yang benar. Sebagaimana pada Penjelasan Umum UUHT angka 7 dijelaskan bahwa Proses pembebanan Hak tanggungan dilaksanakan melalui dua tahap kegiatan, yaitu:

a. Tahap pemberian Hak tanggungan, dengan dibuatnya Akta Pemberian Hak tanggungan oleh Pejabat Pembuat Akta Tanah, untuk selanjutnya disebut PPAT, yang didahului dengan perjanjian utang-piutang yang dijamin;

b. Tahap pendaftarannya oleh Kantor Pertanahan, yang merupakan saat lahirnya Hak tanggungan yang dibebankan.

Pembebanan hak tanggungan diawali dengan dibuatnya akta pemberian hak tanggungan (selanjutnya disingkat APHT) oleh Pejabat Pembuat Akta Tanah (selanjutnya disingkat PPAT), yang didahului dengan perjanjian utang-piutang yang dijamin.

Di dalam pasal 13 ayat (1) dan ayat (2) UUHT, disebutkan bahwa pemberian hak tanggungan wajib didaftarkan pada Kantor Pertanahan. Selambat-lambatnya 7 (tujuh) hari kerja setelah penandatanganan akta pemberian hak tanggungan, PPAT wajib mengirimkan akta pemberian hak tanggungan yang bersangkutan dan warkah lain yang diperlukan kepada Kantor Pertanahan. Menurut penjelasan pasal 13 ayat (2) UUHT, bahwa dengan pengiriman oleh PPAT berarti akta dan warkah lain yang diperlukan itu disampaikan ke Kantor Pertanahan melalui petugasnya atau dikirim melalui pos tercatat. PPAT wajib menggunakan cara yang paling baik dan aman dengan memperhatikan kondisi daerah dan fasilitas yang ada, serta selalu berpedoman pada tujuan untuk didaftarnya Hak tanggungan itu secepat mungkin. Warkah lain yang dimaksud pada ayat ini meliputi surat-surat bukti yang berkaitan dengan obyek Hak tanggungan dan identitas pihak-pihak yang bersangkutan, termasuk di dalamnya sertipikat hak atas tanah dan/atau surat- 
surat keterangan mengenai obyek hak tanggungan. PPAT wajib melaksanakan ketentuan pada ayat ini karena jabatannya. Sanksi atas pelanggarannya akan ditetapkan dalam peraturan perundang-undangan yang mengatur jabatan PPAT.

UUHT tidak menjelaskan mengenai sanksi jika PPAT dalam waktu tidak lebih dari 7 hari belum menyerahkan APHT pada Kantor Pertanahan untuk diproses pembuat sertifikat hak tanggungan, dan apa akibat hukumnya jika sertifikat hak tanggungan dibuat didasarkan atas keterlambatan PPAT menyerahkan APHT. Di dalam Pasal 40 ayat (1) Peraturan Pemerintah Nomor 24 Tahun 1997 tentang Pendaftaran Tanah (selanjutnya disingkat PP No. 24 Tahun 1997) disebutkan bahwa selambat-lambatnya 7 (tujuh) hari kerja sejak tanggal ditandatanganinya akta yang bersangkutan, PPAT wajib menyampaikan akta yang dibuatkannya berikut dokumendokumen yang bersangkutan kepada Kantor Pertanahan untuk didaftar. Sanksi terhadap PPAT sebagaimana pasal 62 PP No. 24 Tahun 1997, bahwa PPAT yang dalam melaksanakan tugasnya mengabaikan ketentuan Pasal 40 serta ketentuan dan petunjuk yang diberikan oleh Menteri atau Pejabat yang ditunjuk dikenakan tindakan administratif berupa teguran tertulis sampai pemberhentian dari jabatannya sebagai PPAT, dengan tidak mengurangi kemungkinan dituntut ganti kerugian oleh pihakpihak yang menderita kerugian yang diakibatkan oleh diabaikannya ketentuan-ketentuan tersebut.

Keterlambatan PPAT mengirimkan berka akta pemberian hak tanggungan dipermasalahkan oleh Wati Rachmawati dan Herizal Febriansyah, mendapat fasilitas kredit dari PT. Bank Shinta Indonesia setelah menyerahkan bidang tanah SHM Nomor 1981/ Kel Sukarasa G.S. No. 647/1978, tanggal 9 Maret 1978, seluas 548 m2, dibuktikan dalam sertifikat Hak Tanggungan (SHT) Peringkat I No. 6837/ 1996 dengan beban Hak Tanggungan hingga sejumlah Rp. 250.000.000,- yang di dalamnya dilekatkan Akta Pemberian 
Hak Tanggungan (APHT) Nomor 602/3/01/Bdg/APHT/1996, tanggal 10 September 1996.

Akta pembebanan hak tanggungan dikirimkan pada Kantor Pertanahan, terjadi keterlambatan misalnya, APHT dikirim ke BPN tanggal 26 September 1996, padahal APHT dibuat pada tanggal 10 September 1996 (terdapat rentang waktu 16 hari). Selanjutnya terhadap APHT pada angka 6 melaporkan ketiga APHT tersebut pada 22 Januari 1997, sementara ketiga APHT nya dibuat pada 6 Januari 1997 (ada rentang waktu 16 hari), sehingga debitur menganggap bahwa APHT tidak sah, dan juga sertipikat hak tanggungan yang diterbitkan adalah tidak sah pula.

Pengadilan Negeri Bandung yang memeriksa pada tingkat pertama dalam putusannya Nomor 168/PDT/G/2007/PN.BDG, amarnya menolak gugatan para Penggugat untuk seluruhnya. Pengadilan Tinggi Bandung yang memeriksa pada tingkat banding dalam putusannya Nomor 328/Pdt/2002/PT.BDG, amarnya menguatkan putusan Pengadilan Negeri Bandung Nomor 168/PDT/G/2007/PN.BDG.

Mahkamah Agung yang memeriksa pada tingkat kasasi dalam putusannya Nomor 1563 K/Pdt/2010, amarnya menolak permohonan kasasi dari Pemohon Kasasi. Hal ini berarti bahwa Mahkamah agung dalam putusannya mengesahkan sertipikat hak tanggungan, meskipun PPAT terlambat menyerahkan APHT. Sebagaimana ditentukan dalam pasal 13 ayat (1) dan ayat (2) UUHT, disebutkan bahwa pemberian hak tanggungan wajib didaftarkan pada Kantor Pertanahan. Selambat-lambatnya 7 (tujuh) hari kerja setelah penandatanganan akta pemberian hak tanggungan, PPAT wajib mengirimkan akta pemberian hak tanggungan yang bersangkutan dan warkah lain yang diperlukan kepada Kantor Pertanahan.

Penelitian ini merupakan kajian yang penting tentang pendaftaran APHT oleh PPAT ke Kantor Pertanahan untuk terbitnya sertipikat hak tanggung, dengan beberapa alasan; Pertama, adanya batasan waktu terhadap PPAT dalam waktu tidak lebih dari 
7 hari menyerahkan APHT pada Kantor Pertanahan untuk diproses pembuat sertipikat hak tanggungan, kedua adanya kewajiban PPAT menyampaikan akta yang dibuatkannya berikut dokumendokumen yang bersangkutan kepada Kantor Pertanahan untuk didaftar, ketiga Mahkamah Agung dalam putusannya Nomor 1563 $\mathrm{K} / \mathrm{Pdt} / 2010$, menolak gugatan dengan alasan penggugat/debitur tidak dapat membuktikan keterlambatan penyampaian akta yang dibuatkannya berikut dokumen-dokumen yang bersangkutan kepada Kantor Pertanahan untuk didaftar. Dalam menganalisis permasalah dalam penelitian ini menggunakan 3 (tiga) teori yaitu :

\section{a. Teori Tanggung Gugat}

Tanggung jawab atau tanggung gugat Negara berkaitan dengan penggunaan wewenang dalam fungsi public service. Menurut Tatiek Sri Djatmiati dalam melaksanakan fungsi tersebut bias timbul keruian atau penderitaan bagi masyarakat. ${ }^{1}$ Timbulnya kerugian bagi masyarakat dapat terjadi karena cacat dalam penggunaan wewenang atau berkaitan dengan perilaku aparat selaku pribadi. Kedua hal tersebut menjadi parameter ada atau tidaknya suatu tangung jawab atau tanggung gugat Negara atas kerugian yang ada.

Penggunaan kewenangan oleh pemerintah menurut konsep hukum Perancis beranjak dari dua prinsip utama yang telah ditetapkan oleh Conseil d'etat sebagai dasar dalam pelayanan publik. Pertama adalah Legalite dan yang kedua adalah Responsabilite. Legalite (legalitas) berarti bahwa pemerintah harus bertindak sesuai dengan hukum, oleh karenanya keutusankeputusannya beresiko untuk dibatalkan oleh pengadilan administrasi. Responsibilite mengindentifikasikan bahwa pemerintah akan bertanggung gugat untuk ganti rugi kerugian bagi

'Tatiek Sri Djatmiati, Kesalahan Pribadi dan Kesalahan Jabatan dalam Tanggung Jawab atau Tanggung Gugat Negara, disampaikan pada "Lokakarya Hukum Administrasi dan Korupsi",Universitas Airlangga, Surabaya, 2008, 3. 
warga yang mengalami kerugian oleh keputusan-keputusan atau tindakan-tindakan pemerintahan. ${ }^{2}$

Tribunal des Conflicts tahun 1873 menetapkan 3 (tiga) asas, yaitu $0^{3}$

1. Asas tanggung gugat Negara atas kesalahan pejabatnya

2. Tanggung gugat tunduk kepada peraturan yang memisahkan dan membedakannya dengan hukum privat

3. Asas bahwa tanggung gugat tersebut merupakan yuridiksi dari peradilan administrasi.

Conseil d'Etat dan juga dari pertimbangan Tribunal des Conflicts kemudian mengembangkan uuran kesalahan untuk tanggung gugat atas kerugian yang ada atas 2 (dua) unsur: ${ }^{4}$

1. Faute Personelle (Kesalahan Pribadi)

Kaitannya dengan tanggung gugat Negara, karena adanya unsur fause personelle, pegawai tersebut dapat digugat oleh seseorang yang dirugikan di pengadilan umum (Ordinary Court) selaku pribadi dan bertanggung gugat atas kesalahan sendiri;

2. Faute de service (Kesalahan Jabatan)

Kaitannya dengan tanggung gugat Negara, yang menekankan unsur kesalahan (faute) juga terlihat keseimbangan perlindungan tersebut. Apabila terdapat suatu faute personelle, maka gugatan tidak dapat diajukan ke pengadilan administrasi. Penyelesaian sengketa apabila terdapat unsur faute de servive, maka gugatan dapat diajukan ke peradilan administrasi dengan berpegangan pada prinsip daar dalam penyelenggaraan pemerintahan yang disebut Les Principles Generaux Du Droi, pelanggaran atas prinsip tersebut

2L. Neville Brown dan John S. Bell, French Administrative Law, (Oxford: Clarendon Press, 1998), 182. Tatiek Sri Djatmiati, Kesalahan Pribadi dan Kesalahan Jabatan Dalam Tanggung Jaw ab atau Tanggung Gugat Negara, disampaikan pada "Lokakarya Hukum Administrasi dan Korupsi",Universitas Airlangga, Surabaya, 2008, 4.

${ }^{3}$ lbid.

${ }^{4}$ bid, 5 . 
dapat dikategorikan bertentangan dengan prinsip Legalite (keabsahan).

b. Teori Kepastian Hukum

Menurut Radbruch sebagaimana dikutip oleh Theo Huijbers Teori Kepastian Hukum adalah : Hubungan antara keadilan dan kepastian hukum perlu diperhatikan. Oleh sebab kepastian hukum harus dijaga demi keamanan dalam negara, maka hukum positif selalu harus ditaati, pun pula kalau isinya kurang adil, atau juga kurang sesuai dengan tujuan hukum. Tetapi terdapat kekecualian, yakni bilamana pertentangan antara isi tata hukum dan keadilan menjadi begitu besar, sehingga tata hukum itu nampak tidak adil pada saat itu tata hukum itu boleh dilepaskan. ${ }^{5}$

Teori Kepastian hukum mengandung 2 (dua) pengertian yaitu pertama adanya aturan yang bersifat umum membuat individu mengetahui perbuatan apa yang boleh atau tidak boleh dilakukan, dan kedua berupa keamanan hukum bagi individu dari kesewenangan pemerintah karena dengan adanya aturan hukum yang bersifat umum itu individu dapat mengetahui apa saja yang boleh dibebankan atau dilakukan oleh Negara terhadap individu. Kepastian hukum bukan hanya berupa pasal-pasal dalam undangundang melainkan juga adanya konsistensi dalam putusan hakim antara putusan hakim yang satu dengan putusan hakim lainnya untuk kasus yang serupa yang telah di putuskan. ${ }^{6}$

Menurut Sudikno Mertokusumo7, kepastian hukum adalah jaminan bahwa hukum dijalankan, bahwa yang berhak menurut hukum dapat memperoleh haknya dan bahwa putusan dapat dilaksanakan. Walaupun kepastian hukum erat kaitannya dengan keadilan, namun hukum tidak identik dengan keadilan. Hukum bersifat umum, mengikat setiap orang, bersifat menyamaratakan,

${ }^{5}$ Theo Huijbers, Filsafat Hukum Dalam Lintasan Sejarah, (Yogyakarta: Kanisius, 1982), 163.

6Peter Mahmud Marzuki, Pengantar IImu Hukum, (Jakarta: Kencana Pranada Media Group, 2008), 158.

7Sudikno Mertokusumo, Bab-bab Tentang Penemuan Hukum, (Bandung: Citra Aditya Bakti, 2007), 160. 
sedangkan keadilan bersifat subyektif, individualistis, dan tidak menyamaratakan.

Kepastian hukum merupakan pertanyaan yang hanya bisa dijawab secara normatif, bukan sosiologi. Kepastian hukum secara normatif adalah ketika suatu peraturan dibuat dan diundangkan secara pasti karena mengatur secara jelas dan logis. Jelas dalam artian tidak menimbulkan keragu-raguan (multi-tafsir) dan logis dalam artian ia menjadi suatu sistem norma dengan norma lain sehingga tidak berbenturan atau menimbulkan konflik norma. Konflik norma yang ditimbulkan dari ketidakpastian aturan dapat berbentuk konsestasi norma, reduksi norma atau distorsi norma. Kepastian hukum menunjuk kepada pemberlakuan hukum yang jelas, tetap, konsisten dan konsekuen yang pelaksanaannya tidak dapat dipengaruhi oleh keadaan-keadaan yang sifatnya subjektif. ${ }^{8}$

\section{c. Konsep Hak Tanggungan}

Hak tanggungan atas tanah beserta benda-benda yang berkaitan dengan tanah, selanjutnya disebut Hak Tanggungan, adalah hak jaminan yang dibebankan pada hak atas tanah sebagaimana dimaksud dalam Undang-undang Nomor 5 Tahun 1960 tentang Peraturan Dasar Pokok-Pokok Agraria, berikut atau tidak berikut benda-benda lain yang merupakan satu kesatuan dengan tanah itu, untuk pelunasan utang tertentu, yang memberikan kedudukan yang diutamakan kepada kreditor tertentu terhadap kreditor-kreditor yang lain ${ }^{9}$

Hak Tanggungan menurut St. Remy Syahdeni menyatakan bahwa Undang-Undang Hak Tanggungan memberikan definisi yaitu Hak Tanggungan atas tanah beserta benda-benda yang berkaitan dengan tanah yang selanjutnya disebut Hak Tanggungan. ${ }^{10}$ Menurut Prof. Budi Harsono mengartikan hak

${ }^{8}$ http://yancearizona.wordpress.com/2008/04/I3/apa-itu-kepastian-hukum/, diakses tanggal 20 Maret 2016.

${ }^{9}$ Purwahid Patrik dan Kashadi, Hukum Jaminan Edisi Revisi dengan UUHT, (Semarang: Fakultas Hukum Universitas Diponegoro, 2006), 52.

IORemy Sjahdeini, Hak Tanggungan Asas-asas, Ketentuan-ketentuan Pokok dan Masalah Yang Dihadapi Oleh Perbankan, (Bandung: Alumni, t.t.), II . 
tanggungan adalah "Penguasaan hak atas tanah, berisi kewenangan bagi kreditur untuk berbuat sesuatu mengenai tanah yang dijadikan agunan. Tetapi bukan untuk dikuasasi secara fisik dan digunakan melainkan untuk menjualnya jika debitur cidera janji dan mengambil selurih atau sebagian sebagai pembayaran lunas hutang debitur kepadanya. ${ }^{11}$

Keberadaan tanah sebagai obyek jaminan dari suatu utang piutang telah dikenal dalam tatanan hukum Indonesia semenjak zaman Kolonial Belanda. Ketentuan yang mengatur tanah dapat dijadikan obyek jaminan dapat ditemukan dalam KUHPerdata yang mengatur bahwa apabila tanah dijadikan jaminan maka akan dibebani dengan hipotik. Ketentuan ini terus berlaku sampai kemudian dilakukan perubahan oleh Undang-Undang Pokok Agraria Nomor 5 Tahun 1960. Menurut Maria S.W. Sumardjono dengan berlakunya Undang-Undang Nomor 5 Tahun 1960 tentang Peraturan Dasar Pokok-Pokok Agraria, Pembentuk UndangUndang menginginkan perangkat aturan tentang Hak Tanggungan, yang baru terealisasi diundangkan pada tanggal 9 April 1996, dengan lahirnya Undang-Undang Nomor 4 Tahun 1996, tentang Hak Tanggungan Atas Tanah Beserta Benda-Benda yang Berkaitan Dengan Tanah (UUHT). Sejak UUHT dinyatakan berlaku, maka lembaga jaminan hipotik dan credietverband sepanjang menyangkut tanah, berakhir masa tugas serta peranannya. ${ }^{12}$

Hak tanggungan yang diatur dalam undang-undang ini pada dasarnya adalah hak tanggungan yang dibebankan pada hak atas tanah. Namun kenyataannya seringkali terdapat adanya bendabenda bangunan, tanaman dan hasil karya, yang secara tetap merupakan kesatuan dengan tanah yang dijadikan jaminan tersebut. ${ }^{13}$

\footnotetext{
I'http://debbyuntar.blogspot.com/20 I I/0I/hak-tanggungan.html diakses tanggal I0 Juli 2017. '2lbid, 5.

${ }^{13} \mid \mathrm{bid}$.
} 
1. Ratio decidendi hakim yang menolak permohonan kasasi pemohon dalam putusan Mahkamah Agung Nomor 1563 K/Pdt/2010

Perkembangan yang telah dan akan terjadi di bidang pengaturan dan administrasi hak-hak atas tanah serta untuk memenuhi kebutuhan masyarakat banyak, selain Hak Milik, Hak Guna Usaha,dan Hak guna bangunan yang telah ditunjuk sebagai obyek Hak tanggungan oleh UUPA, hak pakai atas tanah tertentu yang wajib didaftar dan menurut sifatnya dapat dipindahtangankan, perlu juga dimungkinkan untuk dibebani Hak tanggungan. Berhubung dengan hal-hal tersebutdi atas, perlu dibentuk Undang-undang yang mengatur Hak tanggungan atas tanah beserta benda-benda yang berkaitan dengan tanah, sebagaimana dimaksud dalam UUPA, sekaligus mewujudkan unifikasi Hukum Tanah Nasional. PPAT sebagai pejabat yang mempunyai wewenang membuat akta berhubungan dengan hak tanggungan, nampak dari Konsideran Bagian Mengingat angka 5 menyebut UUHT. Hal ini berarti bahwa PPAT mempunyai wewenang membuat akta pemindahan hak atas tanah sebagaimana dimaksud oleh ketentuan pasal 19, pasal 26 dan yang dimaksud oleh pasal 51 dan 52 UUPA dengan diundangkannya UUHT.

Disebutkan dalam pasal 1 angka 24 PP Nomor 24 Tahun 1997 bahwa PPAT adalah Pejabat umum yang diberi kewenangan untuk membuat akta-akta tanah tertentu. PPAT adalah pejabat umum menurut Boedi Harsono adalah "seorang yang diangkat oleh pemerintah dengan tugas dan kewenangan memberikan pelayanan kepada umum di bidang tertentu". ${ }^{14}$ Sri Winarsi mengemukakan bahwa pengertian "pejabat umum mempunyai karakter yuridis, yaitu selalu dalam rangka hukum publik. Sifat publiknya dapat dilihat dari pengangkatan, pemberhentian dan kewenangan

14Boedi Harsono, "PPAT, Sejarah Tugas dan Kewenangannya", Majalah Renvoi, No. 8.44.IV, 3 Januari 2007, II. 
PPAT". ${ }^{15}$ PPAT sebagai pejabat umum diberi wewenang untuk membuat akta-akta tanah tertentu.

Wewenang menurut Philipus M. Hadjon bahwa kewenangan bersumber pada 3 (tiga) hal, yakni: 1) atribusi, 2) delegasi, dan 3) mandat. Namun dalam hal kewenangan membuat keputusan hanya dapat diperoleh melalui dua cara yaitu melalui: 1) atribusi dan 2) delegasi. Atribusi adalah wewenang yang melekat pada suatu jabatan. Atribusi adalah kewenangan pemerintah dalam melakukan tindakan yang bersumber langsung dari undangundang secara materiil yang artinya secara nyata wewenang tersebut melekat pada jabatannya. Delegasi adalah pelimpahan wewenang. Delegasi diartikan sebagai penyerahan wewenang (untuk membuat besluit) oleh pejabat pemerintahan (Pejabat Tata Usaha Negara) kepada pihak lain dan wewenang tersebut menjadi tanggung jawab pihak lain tersebut. Pihak yang memberi/melimpahkan wewenang disebut delegan dan yang menerima pelimpahan wewenang disebut delegatoris. ${ }^{16}$

PPAT mempunyai wewenang membuat akta yang berhubungan dengan pertanahan. Akta menurut Pitlo adalah surat yang ditanda tangani, diperbuat untuk dipakai sebagai bukti, dan untuk dipergunakan oleh orang, untuk keperluan siapa surat itu dibuat. ${ }^{17}$ Akta dalam bentuk surat, yang menunjukkan bahwa akta tersebut harus dibuat dalam bentuk tulisan. Akta sebagai bukti adanya perjanjian dibuat secara tertulis bahkan dibuat dengan akta otentik, yang memang peraturan menghendaki dibuatnya akta tersebut dalam bentuk akta otentik.Perihal akta otentik di dalam Hukum Perdata diatur pada buku IV Kitab Undang-Undang Hukum Perdata (selanjutnya disingkat KUH Perdata) tentang

\footnotetext{
${ }^{15}$ Sri Winarsi, "Pengaturan Notaris dan Pejabat Pembuat Akta Tanah Sebagai Pejabat Umum", Majalah Yuridika, Vol. 17 No. 2, Fakultas Hukum Universitas Airlangga, Surabaya, Maret, 2002, 186.

16Philipus M. Hadjon, "Tentang Wewenang", Yuridika, No. 5-6 Tahun XII, Fakultas Hukum Universitas Airlangga, Surabaya, September-Oktober, 1997, I dan 130.

${ }^{17}$ Pitlo (Alih Bahasa M. Isa Arief), Pembuktian dan Daluwarsa Menurut Kitab Undang-undang Hukum Perdata Belanda, (Jakarta: Intermasa, 1986), 52.
} 
Pembuktian dan Daluwarsa. Menurut Pasal 1868 KUH Perdata, "Akta otentik ialah suatu akta yang di dalam bentuk yang ditentukan oleh undang-undang dibuat oleh atau di hadapan pegawai-pegawai umum yang berkuasa untuk itu di tempat di mana akta dibuatnya".

Kewenangan PPAT membuat akta-akta tanah tertentu yang menjadi obyek pendaftaran tanah menurut pasal 9 PP Nomor 24 Tahun 1997 di antaranya bidang-bidang tanah yang dipunyai dengan hak milik, hak guna usaha, hak guna bangunan dan hak pakai;tanah hak pengelolaan;tanah wakaf;hak milik atas satuan rumah susun;hak tanggungan; tanah Negara. Jelas bahwa salah satu wewenang PPAT adalah membuat APHT. APHT menurut penjelasan pasal 23 huruf e PP Nomor 24 Tahun 1997 adalah akta pemberian hak tanggungan sebagaimana dimaksud dalam UUHT.

PPAT bertugas pokok melaksanakan sebagian kegiatan pendaftaran tanah dengan membuat akta sebagai bukti telah dilakukannya perbuatan hukum tertentu mengenai hak atas tanah atau Hak Milik Atas Satuan Rumah Susun, yang akan dijadikan dasar bagi pendaftaran perubahan data pendaftaran tanah yang diakibatkan oleh perbuatan hukum itu sebagaimana pasal 2 ayat (1) PP Nomor 37 Tahun 1998. Perbuatan hukum yang dimaksud, di antaranya adalah APHT dan pemberian kuasa membebankan hak tanggungan.Akta PPAT yang dimaksud menurut pasal 1 angka 4 PP Nomor 37 Tahun 1998 adalah akta yang dibuat oleh PPAT sebagai bukti telah dilaksanakannya perbuatan hukum tertentu mengenai hak atas tanah atau Hak Milik Atas Satuan Rumah Susun.

Kaitannya dengan PPAT dan pembebanan hak tanggungan, bahwa perbuatan hukum pembebanan hak atas tanah yang pembuatan aktanya merupakan kewenangan PPAT, meliputi pembuatan akta pembebanan Hak guna bangunan atas tanah Hak Milik sebagaimana dimaksud dalam Pasal 37 Undang-Undang Pokok Agraria dan pembuatan akta dalam rangka pembebanan Hak tanggungan yang diatur dalam Undang-undang ini sebagaimana penjelasan Umum UUHT. 
Pemberian Hak tanggungan didahului dengan janji untuk memberikan Hak tanggungan sebagai jaminan pelunasan utang tertentu, yangdituangkan di dalam dan merupakan bagian tak terpisahkan dari perjanjian utang-piutang yang bersangkutan atau perjanjian lainnya yang menimbulkan utang tersebut. Pemberian Hak tanggungan dilakukan dengan pembuatan Akta Pemberian Hak tanggungan oleh PPAT sesuai dengan peraturan perundangundangan yang berlaku sebagaimana pasal 10 UUHT. Sesuai dengan sifat accessoir dari Hak tanggungan, pemberiannya haruslah merupakan ikutan dari perjanjian pokok, yaitu perjanjian yang menimbulkan hubungan hukum utang-piutang yang dijamin pelunasannya. Perjanjian yang menimbulkan hubungan utangpiutang ini dapat dibuat dengan aktadi bawah tangan atau harus dibuat dengan akta otentik, tergantung pada ketentuan hukum yang mengatur materi perjanjian itu. Dalam hal hubungan utangpiutang itu timbul dari perjanjian utang-piutang atau perjanjian kredit, perjanjian tersebut dapat dibuat di dalam maupun di luar negeri dan pihak-pihakyang bersangkutan dapat orang perseorangan atau badan hukum asing sepanjang kredit yang bersangkutan dipergunakan untuk kepentingan pembangunan di wilayah Negara Republik Indonesia.

Pemberian Hak tanggungan wajib didaftarkan pada Kantor Pertanahan. Selambat-lambatnya 7 (tujuh) hari kerja setelah penandatanganan APHT, PPAT wajib mengirimkan APHT yangbersangkutan dan warkah lain yang diperlukan kepada Kantor Pertanahan. Pendaftaran Hak tanggungan sebagaimana di atas dilakukan oleh Kantor Pertanahan dengan membuatkan bukutanah Hak tanggungan dan mencatatnya dalam buku-tanah hak atas tanah yang menjadi obyek Hak Tanggungan serta menyalin catatan tersebut pada sertipikat hak atas tanah yang bersangkutan, sebagaimana pasal 13 UUHT. Salah satu asas Hak tanggungan adalah asas publisitas. Oleh karena itu didaftarkannya pemberian Hak tanggungan merupakan syarat mutlak untuk lahirnya Hak tanggungan tersebut dan mengikatnya Hak Tanggungan terhadap 
pihak ketiga. Pengiriman oleh PPAT berarti akta dan warkah lain yang diperlukan itu disampaikan ke Kantor Pertanahan melalui petugasnya atau dikirim melalui pos tercatat. PPAT wajib menggunakan cara yang paling baik dan aman dengan memperhatikan kondisi daerah dan fasilitas yang ada, serta selalu berpedoman pada tujuan untuk didaftarnya Hak tanggungan itu secepat mungkin. Warkah lain yang dimaksud pada ayat ini meliputi surat-surat bukti yang berkaitan dengan obyek Hak tanggungan dan identitas pihak-pihak yang bersangkutan, termasuk di dalamnya sertipikathak atas tanah dan/atau surat-surat keterangan mengenai obyek hak tanggungan. PPAT wajib melaksanakan ketentuan pada ayat ini karena jabatannya. Sanksi atas pelanggarannya akan ditetapkan dalam peraturan-perundangundangan yang mengatur jabatan PPAT sesuai dengan pasal 13 UUHT.

Ketentuan pasal 13 UUHT tersebut di atas telah dengan tegas menyebut bahwa PPAT mempunyai wewenang membuat APHT (APHT), dan dalam membuat APHT, dan APHT wajib didaftarkan pada Kantor Pertanahan. Selambat-lambatnya 7 (tujuh) hari kerja setelah penandatanganan APHT, PPAT wajib mengirimkan APHT yang bersangkutan dan warkah lain yang diperlukan kepada Kantor Pertanahan. Dikaitkan dengan ketentuan Pasal 40 PP Nomor 24 Tahun 1997, bahwa selambat-lambatnya 7 (tujuh) hari kerja sejak tanggal ditandatanganinya akta yang bersangkutan, PPAT wajib menyampaikan akta yang dibuatkannya berikut dokumendokumen yang bersangkutan kepada Kantor Pertanahan untuk didaftar. PPAT wajib menyampaikan pemberitahuan tertulis mengenai telah disampaikannya akta sebagaimana dimaksud di atas kepada para pihak yang bersangkutan. Adanya kalimat "PPAT wajib menyampaikan pemberitahuan tertulis mengenai telah disampaikannya akta sebagaimana dimaksud di atas kepada para pihak yang bersangkutan", yang berarti bahwa yang membuktikan telah dikirim atau belum atas APHT tersebut PPAT bukan pemilik obyek hak tanggungan. 
Kenyataannya APHT yang dibuat oleh PPAT sebagaimana dimaksud pada angka 4 dikirimkan kepada Kantor Pertanahan pada 26 September 1996 sementara APHT nya dibuat pada 10 September 1996 (ada rentang waktu 16 hari). APHT angka 6 APHT nya dibuat pada 6 Januari 1997 (ada rentang waktu 16 hari), sehingga pelaporan APHT nya melebihi batas waktu yang diwajibkan undang-undang yaitu paling lama selama 7 hari kerja. Oleh karenanya keempat APHT dimaksud pada angka 4 dan 6 gugatan ini cacat hukum dan karenanya batal demi hukum. Keterlambatan PPAT mengirimkan APHT tersebut dipermasalahkan oleh Wati Rachmawati dan Herizal Febriansyah dan menurutnya berakibat terhadap sertipikat hak tanggungan, namun Mahkamah Agung Nomor 1563 K/PDT/2010, mengabaikan alasan yang diajukan oleh Wati Rachmawati dan Herizal Febriansyah dengan pertimbangan bahwa judex Facti sudah menerapkan hukum secara tepat dan benar menolak gugatan Penggugat karena Penggugat tidak dapat membuktikan dalildalil gugatannya secara tepat dan benar.

Berdasarkan pembahasan sebagaimana tersebut di atas berkaitan dengan ratio decidendi putusan Mahkamah Agung Nomor $1563 \mathrm{~K} / \mathrm{PDT} / 2010$, yang menolak dalil-dalil penggugat (Wati Rachmawati dan Herizal Febriansyah) mengenai cacat hukum APHT karena PPAT mengirimkan berkas APHT lebih dari 7 (tujuh) hari setelah berkas ditandatangani bertentangan dengan ketentuan pasal 13 UUHT. Namun Mahkamah Agung dalam putusannya menolak dalil-dalil kasasi dari Wati Rachmawati dan Herizal Febriansyah dengan pertimbangan pemohon kasasi tidak dapat membuktikan dalil-dalilnya, yang berarti bahwa jika pemohon kasasi dapat membuktikan keterlambatan pengiriman berkas dalam APHT, maka kemungkinan gugatan dikabulkan. Putusan Mahkamah Agung Nomor 1563 K/PDT/ 2010 tersebut adalah tidak tepat, karena yang dibebani pembuktian bukan Wati Rachmawati dan Herizal Febriansyah, melainkan PPAT yang membuat APHT. 
Terhadap keterlambatan pendaftaran APHT oleh PPAT ke Kantor Pertanahan untuk terbitnya sertipikat hak tanggungan, PPAT menurut pasal 1 angka 1 PP Nomor 37 Tahun 1998 adalah pejabat umum yang diberi kewenangan untuk membuat akta-akta otentik mengenai perbuatan hukum tertentu mengenai hak atas tanah atau Hak Milik Atas Satuan Rumah Susun. PPAT adalah pejabat umum yang oleh undang-undang diberi wewenang membuat akta-akta otentik di antaranya adalah akta pemberian hak tanggungan.

Wewenang berkaitan dengan pendaftgaran hak atas tanah termasuk pemberian hak tanggungan termasuk dalam pelaksanaan administrasi pertanahan dan pendaftaran tanah yang tercatat di Kantor Pertanahan harus selalu sesuai dengan keadaan atau status sebenarnya mengenai bidang tanah yang bersangkutan, baik yang menyangkut data fisik mengenai bidang tanah tersebut, maupun mengenai hubungan hukum yang menyangkut bidang tanah itu, atau data yuridis ini, khususnya pencatatan perubahan data yuridis yang sudah tercatat sebelumnya, peranan PPAT sangatlah penting. Menurut ketentuan di dalam Peraturan Pemerintah Nomor 24 Tahun 1997 tentang Pendaftaran Tanah, peralihan dan pembebanan hak atas tanah hanya dapat didaftar apabila dibuktikan dengan akta PPAT.

PPAT sudah dikenal sejak berlakunya Peraturan Pemerintah Nomor 10 Tahun 1961 tentang Pendaftaran Tanah, yang merupakan pelaksana dari UUPA sebelum diundangkannya PP Nomor 24 Tahun 1997. Di dalam peraturan tersebut PPAT disebutkan sebagai pejabat yang berfungsi membuat akta yang bermaksud memindahkan hak atas tanah, memberikan hak baru atau membebankan hak atas tanah.

Fungsi PPAT lebih ditegaskan lagi dalam Undang-undang Nomor 4 Tahun 1996 tentang Hak Tanggungan atas Tanah Beserta Benda-benda Yang Berkaitan Dengan Tanah dan PP Nomor 24 Tahun 1997, yaitu sebagai pejabat umum yang berwenang membuat akta pemindahan hak atas tanah, pembebanan hak atas tanah, dan 
akta-akta lain yang diatur dengan peraturan perundang-undangan yang berlaku dan membantu Kepala Kantor Pertanahan dalam melaksanakan pendaftaran tanah dengan membuat akta-akta yang akan dijadikan dasar pendaftaran perubahan data pendaftaran tanah.

PPAT memiliki tugas pokok yang dapat melakukan kegiatan seperti pendaftaran tanah dengan membuat akta yang menjadi bukti telah dilakukan perbuatan hukum tertentu mengenai hak atas tanah atau hak miliki atas satuan rumah susun yang akan dijadikan dasar untuk pendaftaran yang anda lakukan adalah perubahan data pendaftaran tanah yang diakibatkan oleh perbuatan hukum yang ada Perbuatan hukum disini akan dijelaskan sebagaimana maksudnya. Sehingga memungkin anda tidak terlalu bingung dengan maksud perbuatan hukum. Pertama ada jual beli, lalu tukar menukar, hibah, pemasukan ke dalam perusahaan, pembagian hak bersama, pemberian hak guna bangunan atau hak pakai atas tanah hak milik. Lalu ada pemberian hak tanggungan dan juga terakhir pemberian kuasa membebankan hak tanggungan.

Tugas PPAT berkaitan dengan peralihan hak atas tanah sebagaimana pasal 37 ayat (1) PP Nomor 24 Tahun 1997 adalah peralihan hak atas tanah dan hak milik atas satuan rumah susun melalui jual beli, tukar menukar, hibah, pemasukan dalam perusahaan dan perbuatan hukum pemindahan hak lainnya, kecuali pemindahan hak melalui lelang, hanya dapat didaftarkan jika dibuktikan dengan akta yang dibuat oleh PPAT yang berwenang menurut ketentuan peraturan perundang-undangan yang berlaku. Ketentuan pasal 37 ayat (1) PP Nomor 24 Tahun 1997 tidak menyinggung mengenai pembebanan hak tanggungan, jika dikaitkan dengan ketentuan dalam UUHT, yang berarti termasuk dalam lingkup "perbuatan hukum pemindahan hak lainnya".

Pembuatan akta sebagaimana dimaksud di atas dihadiri oleh para pihak yang melakukan hukum yang bersangkutan dan disaksikan oleh sekurang-kurangnya 2 (dua) orang saksi yang 
memenuhi syarat untuk bertindak sebagai saksi dalam perbuatan hukum itu. Bentuk, isi dan cara pembuatan akta-akta PPAT sebagaimana Pasal 38 PP Nomor 24 Tahun 1997.

PPAT menolak untuk membuat akta, jika mengenai bidang tanah yang sudah terdaftar atau hak milik atas satuan rumah susun, kepadanya tidak disampaikan sertipikat asli hak yang bersangkutan atau sertipikat yang diserahkan tidak sesuai dengan daftar-daftar yang ada di Kantor Pertanahan; atau mengenai bidang tanah yang belum terdaftar, kepadanya tidak disampaikan surat bukti atau surat keterangan Kepala Desa/Kelurahan yang menyatakan bahwa yang bersangkutan menguasai bidang tanah tersebut dan surat keterangan yang menyatakan bahwa bidang tanah yang bersangkutan belum bersertipikat dari Kantor Pertanahan, atau untuk tanah yang terletak di daerah yang jauh dari kedudukan Kantor Pertanahan, dari pemegang hak yang bersangkutan dengan dikuatkan oleh Kepala Desa/Kelurahan; atau salah satu atau para pihak yang akan melakukan perbuatan hukum yang bersangkutan atau salah satu saksi tidak berhak atau tidak memenuhi syarat untuk bertindak demikian; atau salah satu pihak atau para pihak bertindak atas dasar suatu surat kuasa mutlak yang pada hakikatnya berisikan perbuatan hukum pemindahan hak; atau untuk perbuatan hukum yang akan dilakukan belum diperoleh izin Pejabat atau instansi yang berwenang, apabila izin tersebut diperlukan menurut peraturan perundang-undangan yang berlaku; atau obyek perbuatan hukum yang bersangkutan sedang dalam sengketa mengenai data fisik dan atau data yuridisnya; atau tidak dipenuhi syarat lain atau dilanggar larangan yang ditentukan dalam peraturan perundang-undangan yang bersangkutan. Penolakan untuk membuat akta tersebut diberitahukan secara tertulis kepada pihak-pihak yang bersangkutan disertai alasannya sebagaimana pasal 39 PP No. 24 Tahun 1997.

PPAT menolak membuat akta jika bidang tanah telah terdaftar tanpa menyertakan sertipikat aslinya, dikaitkan dengan hak tanggungan sebagaimana pasal 13 ayat N(3) UUHT, bahwa 
Pendaftaran Hak tanggungan dilakukan oleh Kantor Pertanahan dengan membuatkan buku-tanah Hak tanggungan dan mencatatnya dalam buku-tanah hak atas tanah yang menjadi obyek Hak Tanggungan serta menyalin catatan tersebut pada sertipikat hak atas tanah yang bersangkutan. Selambat-lambatnya 7 (tujuh) hari kerja sejak tanggal ditandatanganinya akta yang bersangkutan, PPAT wajib menyampaikan akta yang dibuatkannya berikut dokumen-dokumen yang bersangkutan kepada Kantor Pertanahan untuk didaftar. PPAT wajib menyampaikan pemberitahuan tertulis mengenai telah disampaikannya akta sebagaimana dimaksud di atas kepada para pihak yang bersangkutan.

Di dalam ketentuan Pasal 62 PP Nomor 24 Tahun 1997 disebutkan bahwa PPAT yang dalam melaksanakan tugasnya mengabaikan ketentuan-ketentuan sebagaimana dimaksud dalam Pasal 38, Pasal 39 dan Pasal 40 PP Nomor 24 Tahun 1997 serta ketentuan dan petunjuk yang diberikan oleh Menteri atau Pejabat yang ditunjuk dikenakan tindakan administratif berupa teguran tertulis sampai pemberhentian dari jabatannya sebagai PPAT, dengan tidak mengurangi kemungkinan dituntut ganti kerugian oleh pihak-pihak yang menderita kerugian yang diakibatkan oleh diabaikannya ketentuan-ketentuan tersebut.

Hal di atas berarti bahwa jika PPAT tidak menyampaikan pemberitahuan telah dikirimnya Akta Pemberian Hak tanggungan yang bersangkutan dan warkah lain yang diperlukan kepada Kantor Pertanahan kepada para pihak sebagaimana ditentukan dalam pasal 40 ayat (2) PP No. 24 Tahun 1997 bahwa PPAT wajib menyampaikan pemberitahuan tertulis mengenai telah disampaikannya akta kepada para pihak yang bersangkutan, berarti PPAT telah melanggar ketentuan pasal 40 PP Nomor 24 Tahun 1997, maka konsekuensinya PPAT dapat dikenakan sanksi administratif berupa teguran tertulis sampai pemberhentian dari jabatannya sebagai PPAT, dengan tidak mengurangi kemungkinan dituntut ganti kerugian oleh pihak-pihak yang menderita kerugian 
yang diakibatkan oleh diabaikannya ketentuan pasal 13 UUHT yo pasal 40 PP Nomor 24 Tahun 1997.

Perihal sanksi pemberhentian PPAT dari jabatannya karena telah melalai atau mengabaikan ketentuan pasal 13 UUHT yo pasal 40 PP Nomor 24 Tahun 1997, sebagaimana pasal 10 PP Nomor 37 tahun 1998 yo Perkaban Nomor 1 tahun 2006 menjelaskan ada dua klasifikasi pemberhentian dari jabatan PPAT, diberhentikan dengan hormat dan diberhentikan dengan tidak dengan hormat. PPAT diberhentikan dengan hormat dari jabatannya karena: permintaan sendiri tidak lagi mampu menjalankan tugasnya karena keadaan kesehatan badan atau kesehatan jiwanya, setelah dinyatakan oleh tim pemeriksa kesehatan yang berwenang atas permintaan menteri atau pejabat yang ditunjuk melakukan pelanggaran ringan terhadap larangan atau kewajiban sebagai PPAT diangkat sebagai pegawai negeri sipil atau ABRI; Sedangkan PPAT diberhentikan dengan dengan tidak hormat dari jabatannya, karena: a. melakukan pelanggaran berat terhadap larangan atau kewajiban sebagai PPAT; b. dijatuhi hukuman kurungan/penjara karena melakukan kejahatan perbuatan pidana yang diancam dengan hukuman kurungan atau penjara selama-lamanya 5 (lima) tahun atau lebih berat berdasarkan putusan pengadilan yang sudah memperoleh kekuatan hukum tetap. Ada beberapa pelanggaran dengan berbeda jenis bagi PPAT. Ada pelanggaran ringan seperti meminta uang jasa melebihi ketentuan peraturan di undang-undang. Lalu tidak menyampaikan adanya laporan bulanan untuk mengenai akta yang telah PPAT buat. Merangkap jabatan terutama sebagai pejabat negara, lalu terakhir adalah lain-lain sesuai keputusan dari BPN.

Untuk pelanggaran berat sangat banyak, beberapa terkait pelanggaran hukum lainnya. Berikut pelanggaran berat yang harus dihindari oleh setiap PPAT. Pertama yaitu melakukan pembuatan akta di luar daerah kerjanya. Hal tersebut akan berakibat fatal bagi PPAT. Apabila PPAT melanggar sumpah jabatan sebagai PPAT ketika awal menjabat atau menjalani profesi. Lalu Pembuatan akta mengenai hak atas tanah atau hak milik atas satuan rumah susun 
oleh PPAT yang bersangkuatan, tidak berhak untuk tidak melakukan perbuatan hukum yang dibuktikan dengan akta.

Memperhatikan uraian dan pembahasan berkaitan dengan akibat hukum bagi kreditor atas keterlambatan pendaftaran APHT oleh PPAT ke Kantor Pertanahan dapat dijelaskan bahwa ketentuan pasal 13 ayat (2) UUHT yo pasal 40 ayat (3) PP Nomor 24 Tahun 1997 mengenai kewajiban PPAT mengirimkan akta pemberian hak tanggungan yang bersangkutan dan warkah lain yang diperlukan kepada Kantor Pertanahan. Apabila PPAT tidak mengirimkan pemberitahuan penyerahan akta pemberian hak tanggungan kepada para pihak dalam hal ini debitor, maka menurut Pasal 62 PP Nomor 24 Tahun 1997 akan dikenakan sanksi baik administrasi maupun sanksi keperdataan.

Ketentuan pasal 62 PP Nomor 24 Tahun 1997 disebutkan bahwa "dengan tidak mengurangi kemungkinan dituntut ganti kerugian oleh pihak-pihak yang menderita kerugian yang diakibatkan oleh diabaikannya ketentuan-ketentuan tersebut", terkait dengan perbujatan PPAT melanggar ketentuan dalam PP Nomor 24 Tahun 1997, sehingga dapat dikatakan telah melakukan perbuatan melanggar hukum dan dapat digugat ganti kerugian.

Perihal ganti kerugian adanya perbuatan melawan hukum atau onrechmatige daad, ditentukan dalam Pasal 1365 KUH Perdata, yang menentukan: "Tiap perbuatan melawan hukum, yang membawa kerugian kepada seorang lain, mewajibkan orang yang karena salahnya menerbitkan kerugian itu, menggantikan kerugian tersebut". Apabila memperhatikan ketentuan Pasal 1365 KUH Perdata di atas, di dalamnya terkandung unsur - unsur sebagai berikut:

1. Perbuatan yang melawan hukum (onrechtmatige daad);

2. Harus ada kesalahan;

3. Harus ada kerugian yang ditimbulkan;

4. Adanya hubungan kausal antara perbuatan dan kerugian. ${ }^{18}$ 
Unsur harus ada perbuatan melawan hukum. PPAT yang membuat akta pemberian hak tanggungan, selambat-lambatnya 7 (tujuh) hari kerja setelah penandatanganan akta pemberian hak tanggungan, PPAT wajib mengirimkan akta pemberian hak tanggungan yang bersangkutan dan warkah lain yang diperlukan kepada Kantor Pertanahan sebagaimana pasal 13 ayat (2) UUHT, dan PPAT wajib menyampaikan pemberitahuan tertulis mengenai telah disampaikannya akta sebagaimana dimaksud di atas kepada para pihak yang bersangkutan sebagaimana pasal 40 ayat (2) PP Nomor 24 Tahun 1997. Apabila PPAT tidak menyampaikan pemberitahuan tertulis mengenai telah disampaikannya pemberitahuan kepada para pihak di antaranya debitur, maka dapat dikatakan telah melakukan perbuatan melanggar ketentuan pasal 40 ayat (2) PP Nomor 24 Tahun 1997, sehingga unsur harus ada perbuatan melanggar hukum telah terpenuhi.

Unsur harus ada kesalahan. Perihal kesalahan dalam perbuatan melawan hukum, dalam hukum perdata tidak membedakan antara kesalahan yang ditimbulkan karena kesengajaan pelaku, melainkan juga karena kelalaian atau kurang hati-hatinya pelaku. Ketentuan ini sesuai dengan yang dikemukakan oleh Riduan Syahrani sebagai berikut: "tidak membedakan antara kesalahan dalam kesengajaan dan kesalahan dalam bentuk kurang hati-hati" ${ }^{19}$ PPAT yang telah membuat akta yang tidak sesuai dengan prosedur seharusnya mengetahui bahwa dirinya tidak mempunyai wewenang membuat akta atau memasukan keterangan yang tidak benar, namun tetap melakukannya, yang berarti bahwa perbuatannya tersebut dilakukan secara sengaja. Hal ini berarti bahwa unsur harus ada kesalahan telah terpenuhi.

Unsur harus ada kerugian. Menurut Riduan Syahrani, perihal kerugian dalam perbuatan melawan hukum, "dapat berupa kerugian materiil dan dapat berupa kerugian immateriil". ${ }^{20}$

${ }^{19}$ Riduan Syahrani, Seluk Beluk dan Asas-Asas Hukum Perdata, (Bandung: Alumni, 1999), 279. 20lbid., 280. 
Kerugian dalam bentuk materiil, yaitu kerugian yang jumlahnya dapat dihitung, sedangkan kerugian immateriil, jumlahnya tidak dapat dihitung, misalnya nama baiknya tercemar, mengakibatkan kematian. PPAT yang telah membuat akta yang tidak sesuai dengan prosedur tersebut apabila dalam menjalankan aktivitasnya sebagai PPAT, namun lelang belum dilaksanakan, sehingga unsur kerugian yang timbul tidak terpenuhi.

Adanya hubungan kausal atau hubungan sebab akibat maksudnya yaitu kerugian yang diderita tersebut ditimbulkan atau disebabkan karena perbuatan melawan hukum yang dilakukan oleh pelaku. Hal ini sesuai dengan yang dikemukakan Riduan Syahrani yang mengutip teori Von Kries sebagai berikut: "Suatu hal baru dapat dinamakan sebab dari suatu akibat, apabila menurut pengalaman masyarakat dapat diduga, bahwa sebab itu akan diikuti oleh akibat itu". ${ }^{21} \mathrm{Hal}$ ini berarti bahwa jika terdapat suatu sebab tetapi sebab tersebut tidak menimbulkan suatu kerugian, atau timbul suatu kerugian namun bukan disebabkan oleh pelaku, maka tidak dapat dikatakan adanya suatu hubungan kausa antara perbuatan dengan kerugian yang ditimbulkan. Apabila karena perbuatan PPAT yang telah membuat akta yang tidak sesuai dengan prosedur tetapi masih menjalankan aktivitasnya yang berakibat orang lain menderita kerugian, namun dalam kaitannya dengan keterlambatan menyerahkan APHT tersebut pihak pemilik obyek hak tanggungan tidak dirugikan baik materiil maupun immateriil, sehingga unsur harus ada hubungan kausal antara perbuatan dengan kerugian yang timbul tidak terpenuhi.

Apabila memperhatikan uraian di atas dapat dijelaskan bahwa gugatan ganti kerugian atas dasar perbuatan melawan hukum apabila pelaku melakukan perbuatan yang memenuhi keseluruhan unsur Pasal 1365 KUH Perdata. Mengenai siapa yang diwajibkan untuk membuktikan adanya perbuatan melawan hukum, menurut Pasal 1865 KUH Perdata menentukan: "Setiap orang yang 
mendalilkan bahwa ia mempunyai sesuatu hak, atau guna meneguhkan haknya sendiri maupun membantah suatu hak orang lain, menunjuk pada suatu peristiwa, diwajibkan membuktikan adanya hak atas peristiwa tersebut". Hal ini berarti bahwa dalam perbuatan melawan hukum, yang diwajibkan untuk membuktikan adanya perbuatan melawan hukum adalah pihak yang haknya dilanggar yang harus membuktikan bahwa haknya telah dilanggar oleh orang lain. Oleh karenanya jika pihak yang merasa haknya dirugikan, namun tidak dapat membuktikan adanya pelanggaran hak karena salah satu unsur tidak terpenuhi, maka gugatan ganti kerugian atas dasar perbuatan melawan hukum tidak akan berhasil.

Memperhatikan uraian di atas dapat dijelaskan bahwa PPAT tidak dapat dimintakan pertanggungan gugat berupa ganti kerugian atas dasar telah melakukan perbuatan melawan hukum sebagaimana Pasal 1365 KUH Perdata, karena unsur adanya kerugian dan hubungan kausal antara perbuatan dengan kerugian yang timbul tidak terpenuhi. PPAT meskipun tidak bertanggung gugat secara perdata, karena kelalaian PPAT tersebut dapat dikenakan sanksi sebagaimana ditentukan dalam pasal 62 PP No. 24 Tahun 1997.

\section{Penutup}

Ratio decidendi putusan Mahkamah Agung Nomor 1563 K/PDT/2010, yang menolak dalil-dalil penggugat (Wati Rachmawati dan Herizal Febriansyah) mengenai cacat hukum APHT karena PPAT mengirimkan berkas APHT lebih dari 7 (tujuh) hari setelah berkas ditandatangani bertentangan dengan ketentuan pasal 13 UUHT. Namun Mahkamah Agung dalam putusannya menolak dalil-dalil kasasi dari Wati Rachmawati dan Herizal Febriansyah dengan pertimbangan pemohon kasasi tidak dapat membuktikan dalil-dalilnya, yang berarti bahwa jika pemohon kasasi dapat membuktikan keterlambatan pengiriman berkas dalam APHT, maka gugatan dikabulkan, karena yang dibebani pembuktian bukan Wati Rachmawati dan Herizal Febriansyah, melainkan PPAT yang membuat APHT. 
PPAT yang terlambat mengirimkan akta pemberian hak tanggungan dapat dikatakan melakukan perbuatan melanggar hukum yakni melanggar ketentuan pasal 62 PP Nomor 37 Tahun 1998, namun terhadap keterlambatan tersebut apabila Rachmawati dapat membuktikan dirinya menderita kerugian, namun jika tidak dapat membuktikan, maka PPAT tidak dapat dimintakan pertanggungan gugat berupa ganti kerugian atas dasar telah melakukan perbuatan melawan hukum sebagaimana Pasal 1365 KUH Perdata, karena unsur adanya kerugian dan hubungan kausal antara perbuatan dengan kerugian yang timbul tidak terpenuhi.

\section{Daftar Pustaka}

Djatmiati, Tatiek Sri. Kesalahan Pribadi dan Kesalahan Jabatan Dalam Tanggung Jawab atau Tanggung Gugat Negara. Disampaikan pada "Lokakarya Hukum Administrasi Dan Korupsi", Universitas Airlangga, Surabaya, 2008.

Hadjon, Philipus M. “Tentang Wewenang". Majalah Yuridika, No. 5-

6 Tahun XII, Fakultas Hukum Universitas Airlangga, Surabaya, September-Oktober, 1997.

Harsono, Boedi. "PPAT, Sejarah Tugas dan Kewenangannya". Majalah Renvoi, No. 8.44. IV, 3 Januari 2007.

Huijbers, Theo. Filsafat Hukum Dalam Lintasan Sejarah. Yogyakarta: Kanisius, 1982.

Marzuki, Peter Mahmud. Pengantar Ilmu Hukum. Jakarta: Kencana Pranada Media Group, 2008.

Mertokusumo, Sudikno. Bab-bab Tentang Penemuan Hukum. Bandung: Citra Aditya Bakti, 2007.

Muhammad, Abdulkadir. Hukum Perikatan. Bandung: Citra Aditya Bakti, 1999.

Patrik, Purwahid dan Kashadi. Hukum Jaminan Edisi Revisi Dengan UUHT. Semarang: Fakultas Hukum Universitas Diponegoro, 2006.

Pitlo. Pembuktian dan Daluwarsa Menurut Kitab Undang-undang Hukum Perdata Belanda. Jakarta: Intermasa, 1986. 
Sjahdeini, Remy. Hak Tanggungan Asas-asas, Ketentuan-ketentuan Pokok dan Masalah Yang Dihadapi Oleh Perbankan. Bandung : Alumni, t.th.

Syahrani, Riduan. Seluk Beluk dan Asas-Asas Hukum Perdata. Bandung: Alumni, 2004.

Winarsi, Sri. "Pengaturan Notaris dan Pejabat Pembuat Akta Tanah Sebagai Pejabat Umum". Majalah Yuridika, Vol. 17 No. 2, Fakultas Hukum Universitas Airlangga, Surabaya, Maret, 2002.

http://yancearizona.word press.com/2008/04/13/apa-itu-kepastianhukum/, diakses tanggal 20 Maret 2016.

http://debbyuntar.blogspot.com/2011/01/haktanggungan.html diakses tanggal 10 Juli 2017. 